\title{
Lexical Strategies in Intralingual Translation between Registers
}

\begin{abstract}
Being concerned with (what has hitherto been) a marginal and under-researched area of Translation Studies, viz. intralingual translation, this paper focuses on the particular type of monolingual rewriting which consists in the transformation of specialized LSP texts into a new text type aimed at lay readership. ${ }^{1}$ As a specific example of this type of transformation, the paper investigates the rewriting of pharmaceutical product specifications into medicinal package inserts (so-called patient information leaflets). In Translation Studies terms, in other words, the pharmaceutical texts are treated as source texts and the patient information leaflets as target texts. The paper examines certain core intralingual translation strategies employed to make the specialized information accessible to the non-expert audience. The focus is primarily on strategies employed to convert medical terminology into more lay-friendly wordings. The exact linguistic nature of these strategies is examined, and the ways in which they contribute to target-text lay-friendliness are charted.
\end{abstract}

\section{Keywords}

Intralingual translation, registers, translation strategies, medical terminology

\section{Introduction}

The specific research field in this article is the particular translational phenomenon known as intralingual translation, whose status within Translation Studies has always been marginal. Thus, Zethsen (2009: 810) notes a pronounced research gap within the field, pointing out that

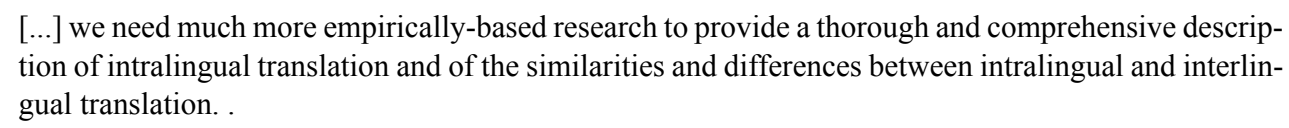

The purpose of this article is thus to take at least a few steps towards filling this empirical gap. Intralingual translation is actually a rather diverse phenomenon (for a typology, see section 2), and the present investigation will confine itself to the particular sub-type which is the most relevant to business communication/LSP research, viz. the type which consists in the rewriting of an expertoriented text type into a lay-friendly one. In Vermeerian terms, the overall skopos ${ }^{2}$ (e.g. Reiß/Vermeer 1984: 96, Vermeer 1996, 2000) of this type of translation is to make information originating in specialized discourse accessible to a lay readership. This skopos is the backdrop against which the specific research purpose of the present article should be seen. The research purpose is twofold: it is, on the basis of an empirical investigation, 1) to determine what particular types of micro-level translation strategies contribute to realizing the skopos of enhanced accessibility, and 2)

1 This article builds on results from a PhD thesis (Hill-Madsen 2014).

2 The reference to skopos theory is made because intralingual translation of the type under investigation here only makes sense within a functionalist paradigm, i.e. one that allows adaptations of the target text in accordance with its function vis-a vis the target audience. Skopos theory is probably the most prominent and most widely accepted functionalist framework.

\footnotetext{
* Aage Hill-Madsen

Department of Business Communication

Aarhus BSS, Aarhus University

Jens Chr. Skous Vej 4

8000 Aarhus $C$

Denmark

ahill@bcom.au.dk
} 
to determine the specific linguistic nature of each strategy. It should be noted, however, that it is beyond an article of the present format to examine all the strategies that may be held to support the skopos of enhanced accessibility, which is why the investigation has been narrowed to ones applying to lexical items. It should also be emphasized that since the investigation is based on English texts only, the findings are limited to intralingual translation between registers in this language. To what extent the findings are applicable beyond English is a question that must be left unanswered. The structure of the article will be the following: first, the specific type of intralingual translation under investigation must be distinguished from other subtypes, to which end section 2 will be devoted to a typologization of the phenomenon as such. A detailed introduction to the data behind the investigation will be given in section 3 , and methodological presuppositions stated in section 4. Section 5 will be concerned with empirical analyses of lexical strategies, and in the final section the analytical results will be discussed from a synoptic point of view, whereby certain general characteristics that, to varying extents, unite the strategies will be identified.

\section{The place of intralingual translation within Translation Studies}

The theoretical point of departure for the present article is Jakobson's (1959) famous tripartite translation typology, which recognizes intralingual translation as one type of translation alongside two others, viz. interlingual and intersemiotic (Jakobson 1959: 233):

1. Intralingual translation or rewording is an interpretation of verbal signs by means of other signs of the same language.

2. Interlingual translation or translation proper is an interpretation of verbal signs by means of some other language.

3. Intersemiotic translation or permutation is an interpretation of verbal signs by means of signs of nonverbal sign systems.

However, despite the 'classic' status of Jakobson's typology, it is still far from uncontroversial to grant translational status to the intralingual derivation of one text from another. Thus, Newmark (1991: 69), Mossop (1998: 252) and Schubert (2005: 126) concede translational status to nothing beyond interlingual translation. Nevertheless, in accordance with Göpferich $(2004,2007)$, Zethsen (2007, 2009), Van Vaerenbergh (2003: 208), Schmid (2008, 2012), and Maßß et al. (2014: 55), the position that will be adopted here is that intralingual rewriting deserves full translational status, and hence full inclusion in the object field of Translation Studies.

In sub-section 2.1, a few arguments will be presented to vindicate the relevance of intralingual translation for Translation Studies, after which an intralingual typology will be proposed (section 2.2 ), in order that the taxonomic identity of the specific type of translation to be investigated here may be clearly established.

\subsection{Incorporation of intralingual translation within Translation Studies}

Before arguments in favour of extending the object field of Translation Studies are presented, it must be conceded that in a certain sense it is quite true that translation equals interlingual translation only, viz. when translation is understood as an institutionalized practice. In the words of Hermans (1995), there is such a thing as

\footnotetext{
a social entity called 'translation' and a form of behaviour called 'translating' with which, give or take a few nuances, we reckon we are all familiar in our own language and culture. The meaning of 'translation' is codified in dictionaries, there are professional activities called translation, we have organizations representing translators, institutes for translator training, etc. It is this 'public face' of translation that I have in mind when I speak of translation as 'institution'.
}

It appears to be this 'institutional' conception of translation which is behind Mossop's (1998) answer to the question "what is a translating translator doing" (the headline of the article). In Mos- 
sop's (1998) conception, translation is characterized by equivalence and sequentiality (i.e. the sequence of meanings in the target must follow that of the source text) apart from interlinguality.

There is no reason to doubt that the characteristics posited by Mossop (1998) match the expectations of stakeholders in the institutionalized practice of translation (commissioners, target-text readers, translators themselves etc.). Yet, it is easy to point out that the real-life work of translators nowadays often goes beyond translation in the narrow sense, all three dimensions of Jakobson's (1959) typology being now reflected in actual practice. Thus, in the words of Stecconi (2007: 17),

\begin{abstract}
[i]ntersemiotic translation has taken on a more practical sense due to the changes brought to the profession by information technology and the internet. These new forms of translating (especially its variety called 'localisation') involve words as well as the nonverbal signs that may appear on a computer screen such as colours, still and moving pictures, and sounds.
\end{abstract}

Similarly, Chesterman (p. c.) has pointed out that there is a significant intralingual component to the work of modern translators: given that the wordings of target texts are often decided on the basis of suggestions generated by machine translation and computerized translation memories, modern translators' activities consist in intralingual text optimization as much as translation.

When it comes to theoretical reasons to extend the concept of translation, an important aspect of Jakobson's (1959) typology that must be emphasized is its broad semiotic orientation. The view taken here is that this broadened perspective is a compelling one, since verbal language is merely one type of semiosis among many, as Stecconi (2007: 17-18) points out, and since the mediation of meaning across a source-target divide involving other semiotic modes than verbal language is indisputably possible (witness e.g. sign language interpreting). It thus makes no sense to restrict the concept of translation to a particular type of conversion within a specific semiotic system (i.e. interlingual translation), and the focus therefore needs to be shifted to mediated semiosis altogether, whether intra- or intersemiotic. ${ }^{3}$ It may even be argued that Jakobson's definition is too narrow, in that it favours verbal language as a necessary ingredient in translation, as pointed out by Tymoczko (2007b: 56, see also Eco 2001: 67), and, in the case of intersemiotic translation, always on the source side. Taking the semiotic approach to its logical conclusion means conferring translational status on conversion between two non-verbal modes of semiosis, as does Gottlieb $(2005,2008)$. It may be argued, of course, that no separate argument has so far been offered in favour of incorporating intralinguality as part of the translation concept. Grounds for this incorporation may be found in what Stecconi (2004) identifies as "the existential conditions of translation." These conditions, or criteria, are a) mediation, b) similarity and c) semiotic difference. In other words, a) translation is a type of semiosis which presupposes an anterior text (in the broadest possible sense of this word, i.e. as any kind of semiotic output) and which 'speaks on behalf of' this source; b) translation implies some kind of commonality in meaning between source and target, and finally c) translation transcends a semiotic barrier, i.e. neutralizes an opposition between source and target in the way meanings are expressed by symbolic form. In the case of interlingual translation, this barrier is easily recognized, but language-internal barriers exist, too, such as the one between mutually unintelligible dialects or the one between an expert and a layman's register (see section 2.2), and it is the existence of such barriers, and the possibility of mediating across them, which makes the nature of intralingual translation at bottom no different from its interlingual sibling: translation of any kind inevitably involves some kind of substitution in form, and such substituting measures are to be found in intersemiotic, interand intralingual translation alike, and with the same fundamental purpose, which is mediation. What needs to be stressed, however, is that granting translational status to intralingual conversions between dialects and registers is at odds with an emphasis on equivalence as a defining characteristic of translation. One exponent of such a conception is Schreiber (1993), according to

3 The concept of intrasemiotic translation, i.e. translation within one and the same sign system, is taken from Toury (1986: 1113-14). In Jakobson's (1959) typology, intra- and interlingual translation are both intrasemiotic, i.e. translation within verbal language. 
whom equivalence is what differentiates translation from adaptation/editing (German: Bearbeitung): in Schreiber's definition (1993: 105), translation presupposes a requirement of invariance, including the highest possible degree of semantic equivalence $(1993: 32,56)$, whereas adaptation/ editing presupposes a requirement of variance of some kind. The view taken here runs counter to such a definition (see also Hill-Madsen 2015: 198), and it should be made absolutely clear that the source and target texts of the present investigation rarely 'mean (quite) the same'. Instead, only varying degrees of relatedness in meaning are observable between sources and targets, which is consistent with Stecconi's criterion of similarity, and with Tymoczko's assertion (2007a: 32) that "equivalence in translation theory and practice can only be a useful concept when it is understood as a form of similarity". It may be added that the nature of the similarity in a given translation must necessarily be skopos-dependent (see also Chesterman 2007: 68). ${ }^{4}$

\subsection{A typology of intralingual translation}

When it comes to a typologization of intralingual translation, the few extant studies more or less concur, albeit with a few deviations. The one that will be adopted here is that of Petrilli (2003: 19-20), ${ }^{5}$ who recognizes the following sub-types: 1) diamesic, 2) diaphasic and 3) diglossic. Of these, the diamesic type consists in translation between the written and the oral mode, with intralingual subtitling as the best real-life example (see e.g. de Linde/Kay 1999: 8-18, Nagel et al. 2009: 45-46). A special case of intralingual subtitling is so-called subtitle respeaking, a technique in use since 2001 (Lambourne 2006), which involves live production of subtitles in connection with live TV broadcasts (see also Jekat 2014). ${ }^{6}$

Diaphasic translation is simply defined by Petrilli as conversion between registers (2003: 20), and is a category that is not sub-divided, although several sub-categories must in fact be recognized. A point of departure for such distinctions may be taken in the interpersonal dimension, i.e. in the source- and target-text readerships involved: thus, the most 'obvious' sub-category is probably the conversion of an expert-oriented source text into a lay-friendly target text (represented by the text pairs of the present investigation). The other 'direction', however, is not only conceivable, but can be seen to occur on a daily basis e.g. in doctors' consultation rooms, where, after listening to the patient's descriptions of his/her ailments, the physician translates it all into the proper medical terminology when making his/her entry in the patient's medical record. A possible third category is one which does involve a shift in register, but in fact not in intended readership from source to target text: this is instanced when e.g. official documents which are already aimed at ordinary citizens are deemed too inaccessible in style and accordingly rewritten into a simplified version (see Maaß et al. 2014), which is a practice that is becoming prevalent in a country like Denmark, and is even mandatory in Germany for certain types of official communication between federal authorities and citizens (Maaß et al. 2014: 53). Similarly, but at a higher level of specialization, intralingual rewriting with no change in target audience occurs when technical documentation or instructions aimed at technicians are rewritten in a simpler, so-called 'controlled language' (see Link 2014).

Finally, the diglossic category is defined by Petrilli (2003: 20) as translation between a standard and non-standard dialect, but this definition needs broadening, as illustrated by the case of the American versioning of the Harry Potter novels (see Denton 2007), which is a clear case of in-

4 For a closer, and very convincing examination of the concept of similarity in relation to translation, see also Chesterman (1996).

5 Another typology that is largely in correspondence with Petrilli's (2003) is one proposed by Gottlieb (2005, 2008). For a non-typological description of intralingual translation, on the other hand, see Zethsen (2009).

6 Some scholars (e.g. Chuang 2006) view the conversion between speech and writing as intersemiotic, but I follow Gottlieb (2008: 56) in not accepting this view, since speech-writing conversion must be regarded as something language-internal, i.e. an intrasemiotic phenomenon. Accepting Chuang's (2006) view would also be at odds with Jakobson's (1959: 233) view of intersemiotic translation as conversion between language as such and a non-linguistic sign system. 
tralingual translation between dialects: since it makes no sense to frame the opposition between American and British English as one between a 'standard' and a 'non-standard' variety of English, diglossic translation must be defined as conversion between dialects as such. (For other examples of the diglossic type of intralingual translation, see Pillière 2010).

\section{Data}

As noted in the introduction, the present article is concerned with the type of intralingual translation in which an expert-oriented source text is rewritten in a lay-friendly register, i.e. diaphasic intralinguality (to use Petrilli's (2003) terminology) of the expert-into-lay sub-type. More specifically, the data consist in two sets of medical texts, of which, in accordance with EU law, one set is derived from the other, and which will accordingly be treated as source and target texts. All texts in the corpus - eight text pairs altogether - have been accessed from the website of the European Medicines Agency ${ }^{7}$, which is the EU authority responsible for approving medicinal products for marketing in EU countries. As for the source texts, the official name of the genre is the Summary of Product Characteristics (henceforth SmPC), and content-wise these texts detail the pharmaceutical data of the medicinal product in question, e.g. therapeutic area, the chemical composition of the drug, dosage instructions etc.. Written by and for medical experts, these texts represent a highly formal and highly specialized, medical register. The target texts for their part belong to the genre known as the Patient Information Leaflet (henceforth PIL), i.e. the small brochure that accompanies medicinal products and which provides information, mostly in non-expert terms, about what the drug is used for and about possible side effects, as well as instructions regarding dosage, about what to do in the event of an overdose etc. In terms of functions, both SmPCs and PILs are thus descriptive as well as instructive/appellative (Van Vaerenbergh 2003: 212).

With regard to style, PILs are legally required to be written in a lay-friendly register: "The package leaflet [i.e. the PIL] should be written in a language understandable by the patient and should reflect the terminology the patient is likely to be familiar with" (European Medicines Agency 2013: 24). Elsewhere, readability (and legibility) is similarly emphasized as a central requirement for PILs:

\footnotetext{
The package leaflet is intended for the patient/user. If the package leaflet is well designed and clearly worded, this maximises the number of people who can use the information, including older people and adolescents, those with poor literacy skills and those with some degree of sight loss. (Directorate General for Enterprise and Industry 2009: 7).
}

The requirement of readability has given rise to a wealth of investigations into the linguistic quality of PILs (see e.g. Hirsch et al. 2008, Askehave/Zethsen 2003, Clerehan/Buchbinder 2006, Van Vaerenbergh 2007), many of which uncover problems in this respect. With just one exception (Piorno 2012 - see below), however, there are no extant studies which investigate PILs from the perspective of intralingual translation, i.e. which trace the specific ways in which PIL wordings are derived from the SmPC source. Two studies (Askehave/Kastberg 2001, Van Vaerenbergh 2007) do chart the derivational relationship between PILs and their SmPC source, but at macro-level both. Thus, Askehave/Kastberg (2001) is concerned with tracing the way that larger chunks of information are transferred between source and target and transformed in the process. Van Vaerenbergh (2007: 172) for her part provides an overview of the overall derivational relation between PIL and SmPC at section level, making it clear that there is no one-to-one relation between SmPC and PIL sections. What she shows is that in most of the individual PIL sections, the content is derived from multiple sections in the SmPC (Van Vaerenbergh 2007: 172).

The only micro-level investigation of the SmPC-PIL relation as a translational one is Piorno (2012), who identifies certain 'de-terminologization procedures', of which some correspond to

7 http://www.ema.europa.eu/ema/. Bibliographical details about each of the eight text pairs are to be found in the Appendix. 
those identified in the present investigation (see section 5), but whose actual micro-level analyses of lexical strategies are very limited.

\title{
4. Methodological presuppositions
}

This section will be concerned with two presuppositions behind the empirical investigation: first, the concept of translation strategy will be defined, after which the particular linguistic orientation which informs the analyses will be briefly accounted for.

\subsection{The concept of strategy}

The research method on which the present investigation is based is the so-called 'coupled-pairs method' (Toury 1995) well known from Translation Studies, consisting in manual, comparative analysis of source and target micro-segments, in this case lexical items. In other words, as part of the investigation, source and target texts have been aligned and target segments related to the source segments from which they could be seen to be derived. Establishing the nature of the source-target relation in a given 'coupled pair' equalled the inference of the specific translation strategy behind the derivation. ${ }^{8}$ With regard to the concept of strategy, the following definition (from Chesterman 1997) will be adopted:

\begin{abstract}
At its simplest, [...] a taxonomy [of strategies] might consist of a single strategy only: Change something. [...] "Change something" could be informally glossed as follows: if you are not satisfied with the target version that comes immediately to mind - because it seems ungrammatical, or semantically odd, or pragmatically weak, or whatever - then change something in it. [...] This grand overall strategy also suggests that one way to look at strategies in more detail is in fact as kinds of changes. Of course, the source text is "changed" anyway in an obvious sense when it is translated into another language; but change as a strategy begins to apply beyond the scope of this obvious change from one language to another. (Chesterman 1997: 92).
\end{abstract}

This definition is obviously phrased with interlingual translation in mind, in relation to which Chesterman appears to equate "the version that comes immediately to mind" with literal translation as a kind of default translation mode. Strategies may thus be defined as the linguistic 'moves' which cause the target to depart from the "shadow text" (Matthiessen 2001: 83) that would come out of a literal translation. As applied to intralingual translation, strategies may likewise be regarded as the changes observable between source and target text, only without the intervening switch in languages. In intralingual translation, in other words, there is no 'shadow text' other than the source text itself.

Since, as mentioned in the introduction, this investigation is focused on lexical items, the concept of lexical strategy needs definition, too, and will be applied to those changes from source to target whose point of departure is a lexical item in the source text. While this may appear tautological, it should be noted that nothing is being said about the nature of the corresponding target item. The reason is that while the derived target unit will in most cases be lexical as well, this is in fact not necessarily the case, but may in certain cases be a multi-word one intermingling lexical and grammatical items (such as determiners, pronouns etc.).

\subsection{Systemic-Functional Grammar}

With regard to linguistic orientation, this article is based on Systemic-Functional Grammar (Halliday/Matthiessen 2014, Matthiessen 1995). Two aspects of SFG are relevant to present purposes, viz. the concept of rank and the concept of metafunction:

8 Space does not permit any more detailed account of the problems connected with identifying micro-level source and target segments in the intralingual translation type being investigated here, i.e. the problems of determining the exact SmPC origin of micro-level target items. For a detailed consideration of this question, see Hill-Madsen (2014: 167-72). 
In grammar, rank equals levels of syntactic organization. SFG recognizes four ranks, viz. clause-phrase ${ }^{9}$ - word-morpheme, with two adjacent ranks being related through constituency. Thus, a word (which consists of morphemes) is a constituent in a phrase, and a phrase in its turn serves as a constituent in a clause (for a more detailed account of the concept of rank, see Matthiessen 1995: 74-77, Halliday/Matthiessen 2014: 7-10).

In Systemic-Functional Linguistics, semantics is conceived of as a functional/communicative phenomenon, and a multifunctional one at that, encompassing more than just referential meaning (Matthiessen 1995: 5). Three different types of meaning - referred to as metafunctions in SFG are in fact recognized, viz. a) an ideational, b) an interpersonal and c) a textual one, all of which are realized in grammatical structures as well as in lexis:

a) The ideational metafunction is equivalent with representational or referential meaning, and, in lexis, is identical with denotation (Matthiessen 1995: 110).

b) The interpersonal metafunction is social meaning, manifesting itself lexically as connotation (Matthiessen 1995: 110).

c) The textual metafunction will be ignored for being irrelevant to present purposes (for an account, see Matthiessen 1995: 111-115), and so will the relation between the three metafunctions and their realization in grammatical structures.

\section{Analyses of lexical strategies in the corpus}

In the investigation on which the present article is based (Hill-Madsen 2014), 13 different types of lexical strategies were identified altogether, not all of which, however, could really be seen to support the lay-oriented skopos of the target texts. A few examples may be given which can hardly be said to contribute to increased readability:

(1) ST: Exposure to ionising radiation is linked with cancer induction and a potential for development of hereditary defects. For diagnostic nuclear medicine investigations the frequency of these adverse reactions is not known.

TT: Any radioactive material may cause cancer or hereditary defects, but the frequency of these adverse reactions is not known. ${ }^{10}$

The italicized items are examples of direct transfer (corresponding to borrowing (Vinay/Darbelnet 1995: 31-32) in interlingual translation) of lexical items from source to target (indeed, the whole clause in which they appear has been 'copy-pasted'). Instead, a target wording like 'it is not known how often these side effects occur' would probably be more lay-friendly. Unfortunately, instances of such direct transfer are quite frequent in the corpus (Hill-Madsen 2014: 261). Another type of strategy whose contribution to the lay-oriented skopos is similarly negligible is the following (the lexical items concerned are italicized):

(2) ST: ... then take the next dose at the regular scheduled time

TT: ... then take your next tablet at the usual time

9 Strictly speaking, the term phrase in SFG is used about prepositional phrases only and is kept distinct from the term group: the two types of unit belong to the same rank, both of them functioning as constituents in clauses, but the difference between the two is that a phrase consists of a preposition + a nominal group (Halliday/Matthiessen 2014: 424). This difference will be ignored here, however, and the traditional term noun phrase (NP) will be used about what is termed a nominal group in SFG.

10 References for the individual examples will be given in the Appendix. What should also be noted is that some of the examples brought in this and the following analytical sections recur in Hill-Madsen (2014). These are: examples 2 (Hill-Madsen 2014: 228); 6, 11, 13, 14, 16, 18 (Hill-Madsen 2014: 235); 20, 23, 26-28 (Hill-Madsen 2014: 236-37); 29-32 (Hill-Madsen 2014: 238); 33, 35, 38-43 (Hill-Madsen 2014: 239); 44, 46, 48, 49 (Hill-Madsen 2014: 248-53), 50 (Hill-Madsen 2014: 247) and 54 (Hill-Madsen 2014: 255). 
(3) ST: Minor dose-dependent reductions in values for forced expiratory volume ...

TT: Gilenya has a slight effect on the lung function.

(4) ST: Laboratory tests [...] require larger blood volumes ...

TT: ... for certain types of blood test your doctor may need to take more blood ...

These are examples of 'pure' synonymy, i.e. synonymy with no shift in e.g. the level of technicality or formality between source and target text. Unlike direct transfer (see example 1), this strategy (synonymy) does involve reformulation, but still cannot be said to enhance the readability of the target text. It should perhaps be emphasized, however, that in the above examples (2-4), as in most cases of 'pure' synonymy in the corpus (Hill-Madsen 2014: 228-232), there is no real need for any other kind of strategy, since it is a matter of target-text synonyms replacing non-technical source items. In the following, attention will be turned to those lexical strategies which can be deemed truly conducive to the skopos of enhanced accessibility. In Hill-Madsen (2014: ch. 8), four such types were identified, namely decrease-in-technicality, decrease-in-formality, non-technical paraphrase and explicitation, to be explored in detail in the following sub-sections. In each sub-section, a definition of the strategy in question will be given first, followed by exemplification of its manifestation in the corpus. All examples have been selected so as to be as representative as possible.

\subsection{Decrease-in-technicality}

A number of studies (Bromme et al. 2001, Bromme et al. 2005, Askehave/Zethsen 2000, 2008) point out that specialized terms constitute a significant obstacle to comprehension for lay readers. Accordingly, shifts which replace technical (in this case medical) terms with non-technical terms must be considered an indispensable strategy in diaphasic, expert-into-lay intralingual translation. With regard to the very concept of technical term, I shall adopt the definition proposed by Meyer/Mackintosh (2000: 113), according to which a technical term is "a lexical item [...] used in a particular domain of expertise" where it is identified with "a rigidly fixed obligatory range of meaning" (2000: 111). The intralingual shift type which is here labelled decrease-in-technicality, then, is manifested when a technical term is replaced by a non-technical, i.e. general-language, equivalent (see also Piorno 2012: 181). However, the possibility of complete 'equivalence' or 'synonymy' between a technical and a non-technical term must - in many cases, at least - be dismissed as a fiction: Technical terms "do not stand in a one-to-one relationship with common-sense terms" (Martin 1993a: 230), the reason being that, as Halliday/Matthiessen (1999: 85) and Martin (1993b: 205) point out, technical terms encode conceptual taxonomies that typically deviate from 'folk' conceptions. Hence, the term decrease-in-technicality will be applied to cases where a target item represents, not a completely synonymous, but nevertheless a close rendering, in non-technical terms, of the denotational content of a source-text technical term. What space does not allow here is any more detailed consideration of the occasional problems associated with identifying technical terms in (source) texts. In most cases, owing to the Greek/Latin origin of most expert medical terms (see Hoste et al. 2010: 18-19), medical terminology is easily recognizable in English, yet borderline cases between specialized and general-language vocabulary are sometimes met with. Once such case is the item administer, which frequently appears in the corpus. The problem with this item is that it is not restricted to medical registers, as is borne out by such collocations as administer justice and administer a sacrament. Suffice it to say that in cases of doubt in the present investigation, Elsevier's Medical Dictionary in Five Languages (Sliosberg 1975) has been consulted, the premise being that if a lexical item is registered in this comprehensive dictionary of medical terms, this equals technical status.

In the individual sub-sections below, the various tendencies in the way decrease-in-technicality is manifested in the intralingual translation of SmPCs into PILs will be charted and exemplified. 


\subsubsection{Etymological aspects of decrease-in-technicality}

One of the most conspicuous aspects of this type of strategy relates to etymology: the tendency is clearly for source items to be of Greek/Latin derivation and for corresponding target items to belong to the original vocabulary of English, i.e. words of Anglo-Saxon descent: ${ }^{11} 12$
(5) lactation $\rightarrow$ breast-feeding
(6) oedema $\rightarrow$ swelling
(7) erythema $\rightarrow$ redness
(8) distension $\rightarrow$ bloating
(9) pharyngolaryngeal $\rightarrow$ throat
(10) somnolence $\rightarrow$ sleepiness
(11) asthenia $\rightarrow$ weakness
(12) abdominal $\rightarrow$ stomach

In other cases, the target item is in fact not of Anglo-Saxon origin, but this makes little difference:

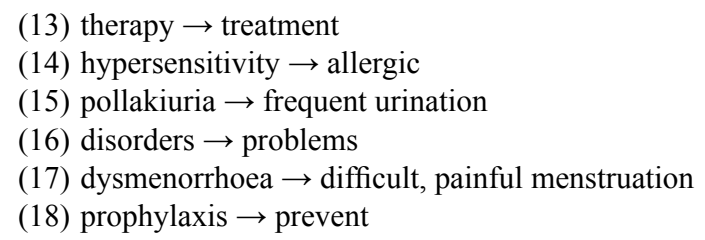

All these target items are ultimately of Greek or Latin origin, but must nevertheless be considered part of the core vocabulary of modern English, and thus well-known to the average lay reader. What some of these pairs illustrate, however, is the consequence of replacing a technical item with a non-technical one: the semantic specificity of the source item is lost and replaced with more general meaning in the target text. This is the case with at least the target items treatment, problems and prevent, where the corresponding source items (therapy, disorders and prophylaxis) are semantically domain-specific, meaning 'medical treatment', 'medical problems' and 'prevention of disease' respectively. However, the loss of semantic specificity in such cases rarely constitutes any problem, since the specific sense in which a given target item is used (e.g. prevent as referring to prevention of disease) is usually to be gathered from the co-text of the item.

\subsubsection{Decrease-in-technicality and word-to-phrase expansion}

As already evidenced by some of the examples in section 5.1.1, there is a pronounced tendency for decrease-in-technicality to result in a target unit consisting in a higher number of words than its source-text counterpart. This was seen in e.g. pollakiuria $\rightarrow$ frequent urination (i.e. a one-word item expanded into a two-word one) and dysmenorrhoea $\rightarrow$ difficult, painful menstruation (one word to three words). In this way, single-word items are expanded into fully-fledged NPs with a Head and one or several Postmodifiers. In Hallidayan terms, this constitutes a shift between ranks, i.e. between word and phrase rank (see section 4).

In some cases of such word-to-phrase expansion, or 'upranking', in connection with decrease-in-technicality, the mechanism is identical to what Vermeer (2008: 7) terms morphem (at) ic translation (reminiscent also of calque in Vinay/Darbelnet's (1995: 32) typology of translation strategies), i.e. translation of the individual morphemes of the (Greek/Latin) source term into core-lexical English words:

(19) gastrointestinal $\rightarrow$ in the stomach or bowels

(20) intravenous $\rightarrow$ into your veins

(21) hypothermia $\rightarrow$ low body temperature

11 Where no other reference is given, information regarding the etymology as well as the meaning of items commented on has been obtained from Kristensen (1962) where Greek/Latin medical terms are concerned, and Hoad (1996) where non-technical items are concerned.

12 What is recorded here are lexemes that correspond to each other across the source-target divide. The items may differ in word class between source and target text because of possible grammatical changes at work in the co-text. 
(22) haematopoietic system $\rightarrow$ the production of ... blood cells

Thus, in (19) gastro- becomes stomach and -intestinal has sparked bowels. In (20), the source-text morpheme intra- is translated into the prepositions into, and -venous becomes vein $(s)$. In the case of hypothermia (21), hypo- is not translated directly as under, which would be the literal meaning, but as low and the source-text morpheme -thermia (=, heat $\left.{ }^{*}\right)$ has found its way into the target text as temperature. Similarly, in haematopoietic system (22), haema(to)- has once become blood in the target text, and -poietic (from poieo = 'make' or 'produce' (Berg 1968: 650)) has resulted in production.

In a number of cases where word-to-phrase expansion forms part of the decrease-in-technicality, however, only part of the target item is a result of direct translation of Greek/Latin morphemes. This tendency was already evidenced in example 17 (hypothermia $\rightarrow$ low body temperature), where the target item body has no base in any specific source-text morpheme. Similar cases are:

(23) hypotension $\rightarrow$ decrease in blood pressure

(24) tachycardia $\rightarrow$ rapid beating of the heart

In (24), the target item heart is derived from-cardia, and rapid from tachy-, but where beating is, at the most, implicit in tachy- and cannot be traced back to any separate source-text morpheme. Example 23 is similar: the target item blood has no explicit source-text origin, while decrease is derived from hypo- and pressure from -tension. Below are listed a handful of examples where the combination of decrease-in-technicality with word-to-phrase expansion is even further removed from a literal translation of Greek/Latin morphemes:

(25) phlebitis $\rightarrow$ inflammation of a vein

(26) uveitis $\rightarrow$ inflammation or infection of the eye

(27) myocardial infarction $\rightarrow$ heart attack

(28) antiarrhythmic $\rightarrow$ for irregular heartbeat

The listing of these four examples is intended as an indication (but an indication only) of a continuum extending away from morphematic translation. Thus, in (25) the target item vein is directly derived from phleb-, whose Greek root does mean 'vein', and inflammation can in fact be traced back to the source-text suffix -itis, which indeed denotes inflammation in the anatomical area in question (Kristensen 1962: 285), but the target item inflammation/infection is obviously not a literal translation, but rather a lexification of this suffix. Parallel examples (not quoted above) are e.g. neuritis $\rightarrow$ inflammation of nerves (GlaxoSmithKline Biologicals S. A 2011: 6 [source] and 34 [target]) and gastritis $\rightarrow$ inflamed stomach (Novo Nordisk A/S 2009: 6 [source] and 24 [target]). In example 26 (from the above list), the target item eye can be seen to originate in uve-, but the Latin root behind this morpheme (uvea) refers to one of the three layers of which the eye is made up (Encyclopedia Britannica Online 2015), which means that the source-target relation in this specific case is meronymic (because the uvea is part of the eye). As for myocardial infarction $\rightarrow$ heart attact (27), the target item heart corresponds directly to -cardial, and the source-text base of the target item attack may be identified as infarction, but this word literally means 'clogging'. No target item directly corresponds to the source-text morpheme my- (= 'muscle'). A completely literal translation of myocardial infarction, in other words, would be clogging of the heart muscle. Finally, in example 28 (antiarrhythmic $\rightarrow$ for irregular heartbeat), the transformation is even further removed from literal translation, since individual semantic elements from the source item may be said to recur in corresponding target elements, but with nothing like a total semantic correspondence: the source-text item anti- recurs in for, -a-recurs in irregular and -rhythmic in heartbeat. 


\subsubsection{Combination with hyperonymy}

Another relatively frequent tendency is for decrease-in-technicality to combine with hyperonymy. ${ }^{13}$ In some cases, the hyperonymy is immediately apparent because two technical hyponyms form the source-text base of one target item, as in:

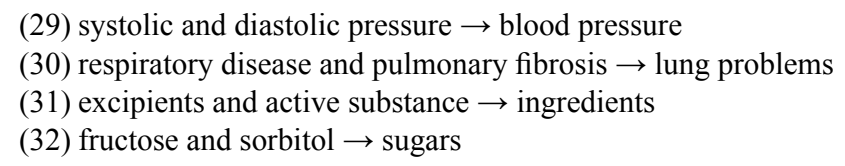

In example 29, both of the two specific types of blood pressure (systolic and diastolic) are represented in the source text, whereas the target text confines itself to using the superordinate item blood pressure, which concurrently represents a decrease-in-technicality (the more technical hyperonym would be arterial pressure (Boulpaep 2012)). Similarly, in (30) the target item lung problems covers the two more specific lung disorders mentioned in the source text, i.e. respiratory disease and pulmonary fibrosis, and in (31) the source items excipients and active substance are subsumed in the target item ingredients. The analysis has not established whether there exist any technical counterparts to the superordinate ingredients and lung problems. The two target items must be considered non-technical, either because they occur outside specialized medical discourse (ingredients) with no change of meaning (as in baking ingredients), or because they are unlikely to occur in expert discourse at all, which may well be the case with both ingredients and lung problems. In (32), on the other hand, (fructose and sorbitol $\rightarrow$ sugars) the technical counterpart to sugars would be saccharides (Daintith 2008: [entry: sugar]).

The combination of decrease-in-technicality with hyperonymy, as in the above cases, is another contribution to the decrease in semantic specificity from source to target, since a hyperonym is obviously more general in meaning than its hyponyms.

\subsection{Decrease-in-formality}

Before the manifestations of this specific strategy are explored, it needs to be considered why two distinct categories (decrease-in-formality vs. decrease-in-technicality) are needed, instead of just one. Thus, in Chesterman's (1997: ch. 4) typology of translation strategies, the two are lumped together as different aspects of one comprehensive category, labelled interpersonal changes, which covers changes in 'the formality level, the degree of emotiveness and involvement, the level of technical lexis and the like: anything that involves a change in the relationship between text/author and the reader' (1997: 110). However, from a Hallidayan perspective, technicality is an ideational (i.e. denotational) aspect of lexis (Eggins 1994: 72-73, 105, see also Halliday/Matthiessen 1999: 85-86), and formality an interpersonal (i.e. connotational) one (Matthiessen 1995: 111). Accordingly, two different categories are needed. Nevertheless, it must be acknowledged that a change in technicality has interpersonal repercussions as well: where knowledge of a subject is unequally distributed between the participants in a communicative situation, the introduction of technical lexis by one communicant will automatically accentuate the knowledge asymmetry, and hence create an unequal power relationship (Eggins/Slade 1997: 148-150). Conversely, it must be assumed that the choice of a non-technical instead of a technical term will help neutralize the knowledge asymmetry and accordingly be conducive to a less formal tenor. Therefore, these interpersonal repercussions will be considered inherent in changes in technicality. The reverse, on the other hand, is not necessarily true: the difference between a formal and a less formal item need in no way have consequences relating to technicality.

Thus, for present purposes, the category decrease-in-formality will be applied to cases where a source-text lexical item which is not restricted to specialized medical registers, but neverthe-

13 Hyperonymy may be defined as a taxonomic relation between a lexical item and its superordinate, i.e. between suband superclass (see Halliday/Matthiessen 2014: 646). An example is the relationship between rose and flower, i.e. with flower as the hyperonym of rose. 
less associated with the registers of academic/bureaucratic/professional discourse ('officialese'), is changed into a more colloquial target item, i.e. an item with a wider registerial currency. A shift of this type thus involves scalar movement, i.e. a move down what Newmark (1988) terms a scale of formality.

Examples of decrease-in-formality from the corpus are:
(33) decrease $\rightarrow$ slow
(34) prior to $\rightarrow$ before
(35) reduction $\rightarrow$ lowers
(36) increased $\rightarrow$ higher
(37) discontinue $\rightarrow$ stop
(38) persistent $\rightarrow$ long-lasting
(39) insufficient $\rightarrow$ not enough

As these examples illustrate, instances of decrease-in-formality exhibit an etymological pattern which parallels the one identified in connection with decrease-in-technicality: in the vast majority of cases, a Latin-derived item is replaced with a core-lexical one of Anglo-Saxon origin, as in all of the above examples. ${ }^{14}$ However, exceptions occur:
(40) inhibit $\rightarrow$ prevent
(41) analogue $\rightarrow$ similar
(42) mitigate $\rightarrow$ reduce
(43) constituents $\rightarrow$ ingredients

Prevent, similar, reduce and ingredients are all ultimately Latin in origin, but these target items must nevertheless be regarded as being closer to core English vocabulary than the corresponding source-text items. Thus inhibit, analogue and mitigate are all categorized as 'formal' in Oxford Advanced Learner's Dictionary (2014 [online] [entries: inhibit, analogue, mitigate]) and constituents (2014 [online] [entry: constituent]) is listed as an academic term.

\subsection{Non-technical paraphrase}

In the words of Chesterman, paraphrase is a translation strategy resulting in a target version that is "loose, free, in some contexts even undertranslated. Semantic components at the lexeme level tend to be disregarded, in favour of the pragmatic sense of some higher unit such as a whole clause" (1997: 104). In accordance with this definition, non-technical paraphrase will be used about target items that, apart from a lower degree of technicality, must be deemed semantically related to, yet distant from, the exact content of the source-text unit, i.e. with specific source-text semantic elements not rendered in the target item. This definition, it must be conceded, makes the category a scalar one, in that distance is obviously a matter of degree. In retrospect, the same can be seen to apply to the category of decrease-in-technicality, defined as a "close rendering ..." (section 4.1). What, it may be asked, is the exact degree of correspondence in meaning for a rendering to qualify as "close"? In fact, the scalarity of decrease-in-technicality was indicated by the illustration of varying degrees of literal translation of ST morphemes (section 4.1.2). In quite the same way, of course, it may be asked what precise degree of 'distance-in-relatedness' is necessary for a source-target pair of items to cross the border into paraphrase. As Martin (1992: 292) points out, however, "it goes without saying [...] that the presence of fuzzy boundaries does not mean that categories do not exist." The two categories will therefore be maintained as conceptually distinct, i.e. as far as their intensional meaning (Murphy/Koskela 2010: 89) is concerned, but with fuzzy borders when it comes to extensions (Murphy/Koskela 2010: 66). In terms of extensions (manifestations in intralingual text pairs), the most prototypical members of the two classes are best viewed as opposite poles on a continuum along which the two categories shade into each other (see also Williams/Chesterman (2010: 95) on the notion of categories interrelated along a

14 As previously, the etymology of items has been ascertained by consulting Hoad (1996). 
continuum). An example from the 'intermediate zone' on the cline, i.e. an instance of ambiguous category membership, is:

(44) atrioventricular conduction delays $\rightarrow$ irregular heartbeat

On the face of it, the two items (source and target) appear to be identical in meaning, but the example is ambiguous because irregular heartbeat appears to be a symptom of, but strictly speaking not the same as, atrioventricular conduction delays, which refers to delays in the electrical impulse (conduction) that makes the heart chambers (atri $[a]$ and ventricl[ es]) contract and expand (Kristensen 1962: 61). These specific components of meaning are not represented in the target item, and the relationship between source and target is one of cause and effect rather than semantic identity. There are good reasons, therefore, to classify the example as non-technical paraphrase rather than decrease-in-technicality.

An instance that is more unambiguously situated within the category of non-technical paraphrase is:

(45) ST [corresponding source and target items italicized]: ... the ELISA method for antibody to human immunodeficiency virus-1 (HIV-1) ...

TT: ... a blood test to look for evidence of infection with certain viruses

Here, it is the indexical nature of the source item antibodies, i.e. as pointers to the presence of infection, which is stressed by the target item evidence of infection as a kind of metonymy for the source item. The two items, however, are far from meaning the same. A similarly unequivocal example is:

(46) ST: A protective immune response may not be elicited in all vaccinees.

TT: As with all vaccines, Pumarix may not fully protect all persons who are vaccinated.

Here, the link between the underlined source and target items may possibly be characterized as logical implication: the possibility that the vaccination may fail to elicit the proper immune response logically lends itself to the inference that the medicine may not offer full protection. Whether this characterization is sound or not, the target version is certainly much less specific in meaning, in that any reference to the medicine's activation of the immune system is absent.

\subsubsection{Combination with 'clause-ification'}

As was seen to be the case with decrease-in-technicality, non-technical paraphrase very often combines with other types of change. Especially prevalent is a phenomenon reminiscent of the word-to-phrase expansion recorded in connection with decrease-in-technicality, in that, as part of the non-technical paraphrase, the source-text word or phrase in question (noun or NP in all cases - see Hill-Madsen 2015) is transformed into a clause in the target text. Thus:

(47) ST: With repeated confirmation of liver transaminases above 5 times the ULN, treatment with Gilenya should be interrupted ...

TT: If your test results indicate a problem with your liver, you may have to interrupt treatment with Gilenya

The underlined source-text phrase is here expanded into a fully-fledged target-text clause complete with Subject (your test results), Verb (indicate) and Complement (a problem with your liv$e r)$. Some of these instances of non-technical paraphrase in combination with 'clause-ification' represent fixed source-target pairs in the intralingual translation of SmPCs into PILs. One such is:

(48) Therapeutic indications $\rightarrow$ what [Duocover] is used for

These are in fact two headlines which recur in most SmPCs and PILs. The underlined target unit is a 'clause-ified' non-technical paraphrase of the source-text unit therapeutic indications because it is a rendering in very general terms of the content of the source-text unit. A semantically more loyal, but also more unwieldy, alternative would be what Duocover is recommended as treatment for. The 'negative' counterpart to this set of headlines is the following pair: 
(49) Contraindications $\rightarrow$ Do not use Mepact

- which also occurs in most SmPC-PIL pairs. A third instance of these fixed sets is

(50) Posology and method of administration $\rightarrow$ How to use Mepact

Here, two specific semantic source-text components, viz. 'dosage' (in posology) and 'give' (administration) disappear in the very non-specific target item use. The target item How, on the other hand, is more closely related to the source-text item method.

\subsection{Explicitation}

The final category of lexical strategies to be examined is explicitation. It ought to be mentioned that the sub-categories to be presented below are all identified by Piorno also (2012: 181) as different aspects of what he collectively refers to as de-terminologization procedures. Here, however, the well-known Translation Studies term explicitation is preferred. According to Vinay and Darbelnet (1995: 342), explicitation is "a stylistic translation technique which consists of making explicit in the target language what remains implicit in the source language because it is apparent from either the context or the situation". Thus, explicitation will be applied to those instances where a target-text lexical item is 'extra' in comparison with the source text (prototypically featuring as an apposition), but serving an explanatory function. This definition, however, highlights the somewhat special character of explicitation as far as the source-target relation is concerned: at least in those cases where the strategy takes the shape of a target-text premodification or apposition (such as where a source text only has e.g. Helsinki, and the target text has Helsinki, the capital of Finland), the translation may in the first place be considered intratextual, i.e. targettext-internal, and only at second remove a translation of a source-text item. Nevertheless, because the target item which constitutes the explicitation ultimately relates to a source-text lexical item, the strategy will be included and examined here.

When it comes to identifying cases of explicitation, the use of parentheses in the target text is a frequent, though obviously not an automatic indicator:

(51) [explicitation italicized]: ST: polyps $\rightarrow$ TT: polyps (a type of growth in the nose)

The target-text parenthesis (a type of growth in the nose) must be interpreted as an insertion explaining the meaning of the medical term polyps in general-language terms. The target-text insert is thus implicitly a definition and may be interpreted as an elliptical copular clause of the specifying kind (see Huddleston/Pullum 2002: 266), which, in full, would be which is/means a type of growth in the nose.

In a limited number of cases, the explicitation consists in exemplification (see also Van Vaerenbergh 2003: 215-216), as in:

(52) ST: DuoCover is indicated for the prevention of atherothrombotic events in adult patients ...

TT: DuoCover is taken to prevent blood clots forming in hardened arteries which can lead to atherothrombotic events (such as stroke, heart attack, or death).

Here, the medical term atherothrombotic events is explained by reference (in lay terms) to specific manifestations of the superordinate concept.

A different type of parenthetical insert is the following:

(53) ST: Patients with a history of venous thrombosis, vasculitis or unstable cardiovascular disorders ...

TT: - if you have or have had problems with your heart or blood vessels, like blood clots (thrombosis), bleeding ${ }^{15}$ (haemorrhage) or inflammation of the veins (vasculitis).

15 The source-text item behind the target item bleeding is to be found in another section of the SmPC (p. 4, section 4.4) than the one quoted above. 
This is in fact the reverse of the type illustrated by example 51, and so prevalent that it ought to be mentioned, although its contribution to the lay-oriented skopos of the PILs is dubious. Thus, in example 53 the function of the parentheses can hardly be characterized as explanatory, since the parenthetical items (thrombosis, haemorrhage, vasculitis) are the medical terms for the preceding target-text items, i.e. blood clots, bleeding and inflammation of the veins, which represent the real intralingual translation (by way of decrease-in-technicality) of the source-text terms. It rather appears that the purpose is disambiguation (Van Vaerenbergh 2003: 215), in that the target text is thus firmly anchored in the source text through specification of what is 'really' being referred to (and hence the precise, medical term) by the non-technical target-text item. Thus, somewhat paradoxically, these parentheses are explicitation based on direct transfer of a source-text item, which means that, from a translation-theoretical point of view, they represent spells of strong source-text orientation in the middle of highly skopos-adapted, i.e. target-oriented, translations. A specific, recurrent source-target pair of this type is the following:

(54) ST: Hypersensitivity to the active substance or to any of the excipients of Avamys

TT: if you are allergic (hypersensitive) to fluticasone furoate or any of the other ingredients of Avamys.

Considering the lay-oriented skopos of the PILs, this practice of appending the medical term - often unlikely to be understood by the average reader - in brackets after the non-technical term is rather dubious, as Askehave and Zethsen (2000: 70) point out, but this is a matter of translation quality assessment, and not the concern of this article.

\section{Conclusion: A synoptic perspective}

This paper has been concerned with charting the exact linguistic nature as well as the translational effects of core lexical strategies in the specific type of intralingual diaphasic translation in which a Patient Information Leaflet is derived from its specialized source, the Summary of Product Characteristics. The investigation identified four specific lexical strategies as core ones in terms of their conduciveness to the lay-oriented skopos of the target texts. These were decrease-in-technicality, decrease-in-formality, non-technical paraphrase and explicitation. During the investigation, certain general characteristics have emerged which, to varying extents, cut across the four strategies, and these characteristics will be noted in conclusion:

First of all, with the possible exception of explicitation, all four strategies contribute to bringing the target texts closer to the registers of everyday, colloquial discourse, thereby creating a tenor that is less marked by interpersonal distance than the one which characterizes the source texts. This is achieved through the choice of target items that are neutral/unmarked with respect to technicality, formality and etymology, and accordingly less 'foreign' to the average reader.

A second, general characteristic consists in absence: as already intimated in section 2.2, semantic invariance is in many cases not a feature of this particular type of translation. In fact, a consequence of replacing medical terminology with core vocabulary (sometimes even in combination with hyperonymy, as we have seen) is a decrease in semantic specificity, which is observable when target items of general meaning are substituted for much more specific source-text meanings. Such semantic 'dilution' is in effect the reverse of the mechanism referred to by Halliday/ Martin as condensation/distillation (1993: 29-30) as a central characteristic of specialized terminology: technical terms often represent a concentration of meanings, in that they "accumulat[e] a number of less specialized meanings in a single lexical item" (1993: 229) - a concentration which is accordingly 'thinned' when the two strategies decrease-in-technicality and non-technical paraphrase are put into practice.

Finally, the semantic 'dilution' is closely linked with a syntactic aspect, in that the word-tophrase expansion often associated with decrease-in-technicality, and the 'clause-ification' which sometimes accompanies non-technical paraphrase, cause the content of single-word source-text items to be 'spread out' across several general-language words, as we have seen. A notable impli- 
cation of this 'spreading out' is the fact that it involves no reduction of syntactic complexity, as might perhaps be expected of intralingual translation aimed at the lay reader (see Gottlieb 2008: 57). What has really been shown to take place is that the syntactic complexity of source-text items is shifted upwards in rank, viz. when morphemically complex words are 'unpacked' as multiword NPs, or when words/NPs are converted into clauses. Nevertheless, it must be assumed that this 'rank-shifted' complexity is more manageable from the lay reader's point of view.

\section{References}

Askehave, Inger/Kastberg, Peter 2001: Intergeneric derivation: On the genealogy of an LSP text. In Text 21 (4), 489513.

Askehave, Inger/Zethsen, Karen Korning 2000: Medical texts made simple - dream or reality? In Hermes - Journal of Language and Communication in Business 25, 53-74.

Askehave, Inger/Zethsen, Karen Korning 2003: Communication barriers in public discourse: the patient package insert. In Document Design 4 (1), 22-41.

Askehave, Inger/Zethsen, Karen Korning 2008: Mandatory genres: The case of European Public Assessment Report (EPAR) summaries. In Text \& Talk 28 (2), 167-191.

Berg, Carl 1968: Groesk-dansk ordbog. Copenhagen: Gyldendal.

Boulpaep, Emile L. 2012: Regulation of arterial pressure and cardiac output. In Boron, Walter F./Boulpaep, Emile L. (eds.), Medical Physiology: A Cellular and Molecular Approach. Philadelphia: Elsevier.

Bromme, Rainer/Jucks, Regina/Wagner, Thomas 2005: How to refer to 'diabetes'? Language in online health advice. In Applied Cognitive Psychology 19 (5), 569-586.

Bromme, Rainer/Rambow, Riklef/Nückles, Matthias 2001: Expertise and estimating what other people know: The influence of professional experience and type of knowledge. In Journal of Experimental Psychology: Applied 7 (4), 317-330.

Chesterman, Andrew 1996: On Similarity. In Target 8 (1), 159-64.

Chesterman, Andrew 1997: Memes of Translation: The spread of ideas in translation theory. Amsterdam/Philadelphia: John Benjamins.

Chesterman, Andrew 2007: Where is similarity? In Arduini, Stefano/Hodgson, Robert Jr. (eds.), Similarity and Difference in Translation. Roma: Edizioni di Storia e Letteratura, 63-75.

Chuang, Ying-Ting 2006: Studying subtitle translation from a multi-modal approach. In Babel 52 (4), 372-383.

Clerehan, Rosemary/Buchbinder, Rachel 2006: Towards a more valid account of functional text quality: The case of the patient information leaflet. In Text \& Talk 26 (1), 39-68.

Daintith, John 2008: A Dictionary of Chemistry. Oxford: Oxford University Press.

de Linde, Zoë/Kay, Neil 1999: The Semiotics of Subtitling. Manchester: St Jerome.

Denton, John 2007: “...waterlogged somewhere in mid-Atlantic.” Why American readers need intralingual translation but don't often get it. In TTR: Traduction, Terminologie, Rédaction 20 (2), 243-70.

Directorate General for Enterprise and Industry 2009: Guideline on the readability of the labelling and package leaflet of medicinal products for human use [online]. http://ec.europa.eu/health/files/eudralex/vol-2/c/2009_01_12_readability_guideline final_en.pdf (accessed 09.10.2014).

Eco, Umberto 2001: Experiences in Translation. Translated by McEwen, Alastair. Toronto: University of Toronto Press.

Eggins, Suzanne 1994: An Introduction to Systemic Functional Linguistics. London: Pinter.

Eggins, Suzanne/Slade, Diana 1997: Analyzing Casual Conversation. London: Cassell.

Encyclopedia Britannica Online 2015: Human eye [online]. http://global.britannica.com/EBchecked/topic/1688997/ human-eye (accessed 21.04.2015).

European Medicines Agency 2013: Quality Review of Documents human product-information annotated template (English) version 9 [online]. http://www.ema.europa.eu/docs/en_GB/document library/Template_or_form/2009/10/ WC500004368.pdf (accessed 09.10.2014).

GlaxoSmithKline Biologicals S. A 2011: Pumarix: EPAR - Product Information [online]. http://www.ema.europa. eu/docs/en_GB/document_library/EPAR__Product_Information/human/001212/WC500104693.pdf $\quad$ (accessed 09.10.2014).

Gottlieb, Henrik 2005: Multidimensional Translation: Semantics turned Semiotics. In Gerzymisch-Arbogast, Heidrun/ Nauert, Sandra (eds.), Challenges in Multidimensional Translation : Conference Proceedings. Saarbrücken: MuTra. 
Gottlieb, Henrik 2008: Multidimensional translation. In Schjoldager, Anne (ed.), Understanding Translation. Aarhus: Academica, 39-65.

Göpferich, Susanne 2004: Wie man aus Eiern Marmelade macht: Von der Translationswissenschaft zur Transferwissenschaft. In Göperich, Susanne/Engberg, Jan (eds.), Qualität fachsprachlicher Kommunikation. Tübingen: Gunter Narr Verlag, 3-30.

Göpferich, Susanne 2007: Translation Studies and Transfer Studies. In Gambier, Yves/Shlesinger, Miriam/Stolze, Radegundis (eds.), Doubts and Directions in Translation Studies : Selected Contributions from the EST Congress, Lisbon 2004. Amsterdam/Philadelphia: John Benjamins, 27-39.

Halliday, M. A. K./Martin, J. R. (eds.) 1993: Writing Science: Literacy and Discursive Power. London: Falmer Press.

Halliday, M. A. K./Matthiessen, Christian M. I. M. 1999: Construing Experience through Meaning: A Language-based Approach to Cognition. London: Cassell.

Halliday, M. A. K./Matthiessen, Christian M. I. M. 2014: Halliday's Introduction to Functional Grammar. 4th ed. London/New York: Routledge.

Hermans, Theo 1995: Translation as institution. In Snell-Hornby, Mary/Jettmarova, Zuzana/Kaindl, Klaus (eds.), Translation as Intercultural Communication: Selected Papers from the EST Congress, Prague 1995. Amsterdam/ Philadelphia: John Benjamins, 3-20.

Hill-Madsen, Aage 2014: Derivation and Transformation: Strategies in Lay-oriented Intralingual Translation. Aarhus: Aarhus University. [PhD Thesis].

Hill-Madsen, Aage 2015: The 'unpacking' of grammatical metaphor as an intralingual translation strategy: From demetaphorization to clausal paraphrase. In Maksymski, Karin/Gutermuth, Silke/Hansen-Schirra, Silvia (eds.), Translation and Comprehensibility. Berlin: Frank \& Timme, 195-226.

Hirsch, Di/Clerehan, Rosemary/Staples, Margaret/Osborne, Richard H./Buchbinder, Rachel 2008: Patient assessment of medication information leaflets and validation of the Evaluative Linguistic Framework (ELF). In Patient Education and Counselling 77, 248-54.

Hoad, T. F. 1996: Concise Dictionary of English Etymology. Oxford: Oxford University Press.

Hoste, Véronique/Vanopstal, Klaar/Lefever, Els/Delaere, Isabella 2010: Classification-based scientific term detection in patient information. In Terminology 16 (1), 1-29.

Huddleston, Rodney/Pullum, Geoffrey K. 2002: The Cambridge Grammar of the English language. Cambridge: Cambridge University Press.

Jakobson, Roman 1959: On linguistic aspects of translation. In Brower, Reuben A. (ed.), On Translation. Cambridge: Harvard University Press, 232-239.

Jekat, Susanne J. 2014: Respeaking: Syntaktische Aspekte des Transfers. In Jekat, Susanne J./Jüngst, Heike Elisabeth/ Schubert, Klaus/Villiger, Claudia (eds.), Sprache barrierefrei gestalten: Perspektive aus der angewandten Linguistik. Berlin: Frank \& Timme, 87-108.

Kristensen, Martin 1962: Klinisk ordbog. Copenhagen: Høst \& Søn.

Lambourne, Andrew 2006: Subtitle respeaking: A new skill for a new age. In Intralinea 8.

Link, Lisa 2014: Reguliertes English in der Technischen Dokumentation. Unterschiedliche Ziele im Hinblick auf die Optimierung der Fachkommunikation. In Jekat, Susanne J./Jüngst, Heike Elisabeth/Schubert, Klaus/Villiger, Claudia (eds.), Sprache barrierefrei gestalten: Perspektiven aus der angewandten Linguistik. Berlin: Frank \& Timme.

Martin, J. R. 1992: English text: System and Structure. Amsterdam/Philadelphia: John Benjamins.

Martin, J. R. 1993a: Life as a noun: Arresting the universe in science and humanities. In Halliday, M. A. K./Martin, J. R. (eds.), Writing Science: Literacy and Discursive Power. London: Falmer Press, 221-267.

Martin, J. R. 1993b: Technicality and abstraction: Language for the creation of specialized texts. In Halliday, M. A. K./ Martin, J. R. (eds.), Writing Science : Literacy and Discursive Power. London: Falmer Press, 203-20.

Matthiessen, Christian M. I. M. 1995: Lexicogrammatical cartography: English systems. Tokyo: International Language Sciences.

Matthiessen, Christian M. I. M. 2001: The environments of translation. In Steiner, Erich/Yallop, Colin (eds.), Exploring Translation and Multilingual Text Production: Beyond Content. Berlin/New York: Morton de Gruyter, 41-124.

Meyer, Ingrid/Mackintosh, Kristen 2000: When terms move into our everyday lives: An overview of de-terminologization. In Terminology 6 (1), 111-38.

Mossop, Brian 1998: What is a translating translator doing? In Target 10 (2), 231-66.

Murphy, M. Lynne/Koskela, Anu 2010: Key Terms in Semantics. London/New York: Continuum. 
Maaß, Christiane/Rink, Isabel/Zehrer, Christiane 2014: Leichte Sprache in der Sprache- und Übersetzungswissenschaft. In Jekat, Susanne J./Jüngst, Heike Elisabeth/Schubert, Klaus/Villiger, Claudia (eds.), Sprache barrierefrei gestalten: Perspektiven aus der angewandten Linguistik. Berlin: Frank und Timme, 53-86.

Nagel, Silke/Henkel, Susanne/Hinderer, Katharina/Pieper, Karin 2009: Audiovisuelle Übersetzung. Frankfurt a. M.: Peter Lang.

Newmark, Peter 1988: A Textbook of Translation. Hertfordshire: Prentice-Hall.

Newmark, Peter 1991: About Translation. Clevedon: Multilingual Matters.

Novo Nordisk A/S 2009: Victoza: EPAR - Product Information [online]. http://www.ema.europa.eu/docs/en_GB/document library/EPAR _ Product Information/human/001026/WC500050017.pdf (accessed 09.10.2014).

Oxford Advanced Learner's Dictionary 2014 [online]. http://oald8.oxfordlearnersdictionaries.com/ (accessed 09.10.2014).

Petrilli, Susan 2003: Translation and semiosis. Introduction. In Petrilli, Susan (ed.), Translation Translation. Amsterdam/New York: Rodopi, 17-37.

Pillière, Linda 2010: Conflicting voices: An analysis of intralingual translation from British English to American English. In E-rea 8 (1), 1-10.

Piorno, Pilar Ezpeleta 2012: An example of genre shift in the medicinal product information genre system. In Linguistica Antverpiensia New Series - Themes in Translation Studies 11, 173-86.

Reiß, Katharina/Vermeer, Hans J. 1984: Grundlegung einer allgemeinen Translationstheorie. Tübingen: Max Niemeyer Verlag.

Schmid, Benjamin 2008: A duck in rabbit's clothing: Integrating intralingual translation. In Kaiser-Cooke, Michele (ed.), Das Entenprinzip: Translation aus neuen Perspektiven. Bern: Peter Lang, 19-80.

Schmid, Benjamin 2012: A bucket or a searchlight approach to defining translation? Fringe phenomena and their implications for the object of study. In Herrero, Isis/Klaiman, Todd (eds.), Versatility in Translation Studies: Selected Papers of the CETRA Research Seminar in Translation Studies 2011. Leuven: KU Leuven.

Schreiber, Michael 1993: Übersetzung und Bearbeitung: Zur Differenzierung und Abgrenzung des Übersetzungsbegriffs. Tübingen: Gunter Narr Verlag.

Schubert, Klaus 2005: Translation studies: Broaden or deepen the perspective? In Dam, Helle V./Engberg, Jan/Gerzymisch-Arbogast, Heidrun (eds.), Knowledge Systems and Translation. Berlin: Walter de Gruyter, 125-46.

Sliosberg, A. 1975: Elsevier's Medical Dictionary in Five Languages: English/Amercian / French / Italian / Spanish And German. Amsterdam/Oxford/New York: Elsevier Scientific Publishing Company.

Stecconi, Ubaldo 2004: Interpretive semiotics and translation theory: The semiotic conditions to translation. In Semiotica 150 (1), 471-89.

Stecconi, Ubaldo 2007: Five reasons why semiotics is good for Translation Studies. In Gambier, Yves/Shlesinger, Miriam/Stolze, Radegundis (eds.), Doubts and Directions in Translation Studies: Selected Contributions from the EST Congress, Lisbon 2004. Amsterdam/Philadelphia: John Benjamins, 15-26.

Toury, Gideon 1986: Translation: A cultural-semiotic perspective. In Sebeok, Thomas A. (ed.), Encyclopedic Dictionary of Semiotics. Berlin: Mouton de Gruyter, 1111-24.

Toury, Gideon 1995: Descriptive Translation Studies - and beyond. Amsterdam/Philadelphia: John Benjamins.

Tymoczko, Maria 2007a: Difference in similarity. In Arduini, Stefano/Hodgson, Robert Jr. (eds.), Similarity and Difference in Translation. Roma: Edizioni di Storia e Letteratura, 27-43.

Tymoczko, Maria 2007b: Enlarging Translation, Empowering Translators. Manchester: St. Jerome.

Van Vaerenbergh, Leona 2003: Fachinformation and Packungsbeilage: Fachübersetzung oder mehrsprachiges interund intrakulturelles Technical Writing? In Schubert, Klaus (ed.), Übersetzen und Dolmetschen: Modelle, Methoden, Technologie. Tübingen: Gunter Narr Verlag, 207-224.

Van Vaerenbergh, Leona 2007: Wissensvermittlung und Anweisungen im Beipackzettel. Zu Verständlichkeit und Textqualität in der Experten-Nichtexperten-Kommunikation. In Villiger, Claudia/Gerzymisch-Arbogast, Heidrun (eds.), Kommunikation in Bewegung: Multimedialer und multilingualer Wissenstransfer in der Experten-Laien-Kommunikation. Frankfurt a. M.: Peter Lang, 167-185.

Vermeer, Hans J. 1996: A skopos theory of translation (Some arguments for and against). Heidelberg: TexTconText.

Vermeer, Hans J. 2000: Skopos and commission in translational action. Translated by Chesterman, Andrew. In Venuti, Lawrence (ed.), Translation Studies Reader. Florence, KY, USA: Routledge, 221-32.

Vermeer, Hans J. 2008: Translation today: Old and new problems. In Pym, Anthony/Shlesinger, Miriam/Simeoni, Daniel (eds.), Beyond Descriptive Translation Studies: Investigations in Homage to Gideon Toury. Amsterdam/Philadelphia: John Benjamins, 3-16. 
Vinay, Jean-Paul/Darbelnet, Jean 1995: Comparative Stylistics of French and English: A Methodology for Translation. Translated by J. C. Sager/M.-J. Hamel. Amsterdam/Philadelphia: John Benjamins.

Williams, Jenny/Chesterman, Andrew 2010: The Map: A Beginner's Guide to Doing Research in Translation Studies. Manchester: St. Jerome Publishing.

Zethsen, Karen Korning 2007: Beyond Translation Proper. In TTR: Traduction, Terminologie, Redaction 20 (1), 281308 .

Zethsen, Karen Korning 2009: Intralingual translation: An attempt at description. In Meta 54 (4), 795-812. 


\section{Appendix}

Each of the eight texts sampled for the present investigation contains both the source text (SmPC) and target text (PIL). In the list below, the texts will be referred to by the name of the medicinal product concerned. These names (followed by author-date reference) are:

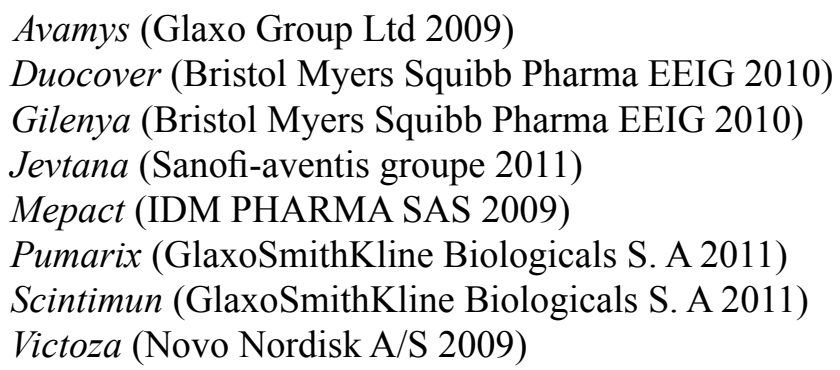

The following is a list giving the exact page and section references for each of the 54 examples in the article. The style of reference adopted will be the following:

(1) Scintimun. ST: 6-4.8, TT: $26-4$

For the ST, 6 refers to the page number, and 4.8 to the section. Similarly, for the TT 26 is the page number, and 4 is the section.

(2) Duocover. ST: 3-4.2, TT: 49-3

(3) Gilenya. 6-4.4, 37-2

(4) Gilenya. 6-4.4, 38-2

(5) Jevtana. 6-4.6, 28-2

(6) Mepact. 6-4.8, 25-4

(7) Mepact. 5-4.8, 25-4

(8) Mepact. 6-4.8, 25-4

(9) Mepact. 6-4-8, 25-4

(10) Mepact. 5-4.8, 25-4

(11) Pumarix. 5-4.8, 33-4

(12) Pumarix. 5-4.8, 33-4

(13) Gilenya. 5-4.4, 37-2

(14) Jevtana. 4-4.4, 28-2

(15) Mepact. 6-4.8, 25-4

(16) Mepact. 6-4.8, 25-4

(17) Mepact 6-4.8, 25-4

(18) Pumarix. 2-4.1, 31-1

(19) Duocover. 9-4.8, 50-4

(20) Mepact. 3-4.2, 24-3

(21) Mepact. 6-4.8, 25-4

(22) Scintimun. 4-4.5, 25-2

(23) Gilenya. 6-4.5, 36-2

(24) Mepact. 5-4.8, 25-4

(25) Mepact. 5-4.8, 25-4

(26) Gilenya. 5.4.4, 37-2

(27) Duocover. 2-4.2, 49-3

(28) Gilenya. 4-4.4, 36-2 
(29) Gilenya. 6-4.4, 37-2

(30) Gilenya. 6-4.4, 37-2

(31) Pumarix. 3-4.3, 31+32-2

(32) Scintimun. 4-4.4, 25-2

(33) Gilenya. 3-4.4, 36-2

(34) Gilenya. 4-4.4, 36-2

(35) Gilenya. 4-4.4, 37-2

(36) Gilenya. 5-4.4, 37-2

(37) Gilenya. 4-4.4, 39-3

(38) Mepact. 3-4.4, 23-2

(39) Victoza. 2-4.1, 22-1

(40) Duocover. 11-5.1, 48-2

(41) Mepact. 2-1, 23-1

(42) Jevtana. 2-4.2, 29-3

(43) Pumarix. 3-4.3, 31-2

(44) Gilenya. 3-4.4, 36-2

(45) Pumarix. 4-4.5, 32-2

(46) Pumarix. 3-4.4, 31-1

(47) Gilenya. 5-4.4, 37-2

(48) Duocover. 2-4.1, 47-1

(49) Mepact. 3-4.3, 23-2

(50) Mepact. 2-4.2, 24-3

(51) Duocover. 3-4.3, 47-2

(52) Duocover. 2-4.1, 47-1

(53) Mepact. 3-4.4, 23-2

(54) Avamys. 3-4.3, 18 -2.

\section{References}

Bristol Myers Squibb Pharma EEIG 2010: Duocover: EPAR - Product Information [online]. http://www.ema.europa. eu/docs/en_GB/document library/EPAR_-_Product_Information/human/001144/WC500087030.pdf (accessed 09.10.2014).

Glaxo Group Ltd 2009: Avamys: EPAR - Product Information [online]. http://www.ema.europa.eu/docs/en_GB/document_library/EPAR _ Product_Information/human/000770/WC500028814.pdf (accessed 09.10.2014).

GlaxoSmithKline Biologicals S. A 2011: Pumarix: EPAR - Product Information [online]. http://www.ema.europa. eu/docs/en GB/document library/EPAR - Product Information/human/001212/WC500104693.pdf (accessed 09.10.2014).

IDM PHARMA SAS 2009: Mepact: EPAR - Product Information [online]. http://www.ema.europa.eu/docs/en_GB/ document_library/EPAR - Product_Information/human/000802/WC500026565.pdf (accessed 09.10.2014).

Novo Nordisk A/S 2009: Victoza: EPAR - Product Information [online]. http://www.ema.europa.eu/docs/en_GB/document_library/EPAR__Product_Information/human/001026/WC500050017.pdf (accessed 09.10.2014).

Sanofi-aventis groupe 2011: Jevtana: EPAR - Product Information [online]. http://www.ema.europa.eu/docs/en_GB/ document_library/EPAR__Product_Information/human/002018/WC500104764.pdf (accessed 09.10.2014). 